\title{
Response of banana genotypes to yellow Sigatoka in coastal tablelands of Sergipe, Brazil ${ }^{1}$
}

\author{
Resposta à Sigatoka amarela de genótipos de bananeira nos tabuleiros costeiros de \\ Sergipe, Brasil
}

\author{
Zilná Brito de Rezende Quirino², Ana da Silva Lédo ${ }^{3 *}$, Viviane Talamini ${ }^{3}$ Lucas Fonseca Menezes Oliveira² e \\ Kelly Cristina dos Santos Teixeira ${ }^{4}$
}

\begin{abstract}
Brazil has low availability of productive commercial cultivars with appropriate size and resistance to yellow Sigatoka. The objective of this study was to evaluate the behavior of different banana genotypes against yellow Sigatoka at conditions of Coastal Tablelands of Sergipe. The experiment was conducted at the Experimental Field of Embrapa Tabuleiros Costeiros, municipality of Nossa Senhora das Dores. The experimental design was randomized blocks design with 22 genotypes and three replications, six plants per plot. The genotypes tested were: Enxerto-33, Japira-106, FHIA-23, YB42-17, YB42-47, FHIA-18, PA42-44, PA94-01, PV79-34, Pacovan Ken, Pacovan, Prata-Anã, Maravilha, Garantida, Princesa, Tropical, Maçã, Grande Naine, FHIA-02, Caipira, Bucaneiro and Thap Maeo. The severity of yellow Sigatoka was evaluated at 60, 270 and 420 days after planting (DAP) (from July/2009 to July/2010), using a descriptive scale of Stover. Then, the infection rate was calculated at 60, 270 and 420 DAP, and was compared by Scott-Knott test at $5 \%$. It was observed that genotypes have the same behavior at 270 DAP. At 60 DAP, genotypes with lower infection rate were Bucaneiro, Enxerto-33, Japira-106, YB42-17, FHIA-02, FHIA-18, FHIA-23, PA42-44, PA94-01, Caipira, Maçã, PrataAnã and Thap Maeo. At 420 DAP, the lowest rates were obtained for genotypes YB42-17, FHIA-23, Princesa, YB42-47, Tropical, Grand Naine, Caipira, Maçã, Garantida, Bucaneiro, Pacovan Ken and Thap Maeo.
\end{abstract}

Key words: Musa spp.. Banana-Breeding. Plants-Resistance.

RESUMO - O Brasil tem baixa disponibilidade de cultivares comerciais produtivas com porte adequado e resistência à Sigatoka amarela. O objetivo deste estudo foi avaliar o comportamento de diferentes genótipos de bananeira em relação à Sigatoka amarela em condições de tabuleiros costeiros de Sergipe. O experimento foi conduzido no Campo Experimental da Embrapa Tabuleiros Costeiros, no município de Nossa Senhora das Dores. O delineamento experimental foi de blocos ao acaso com 22 genótipos e três repetições, seis plantas por parcela. Os genótipos testados foram: Enxerto-33, Japira-106, FHIA23, YB42-17, YB42-47, FHIA-18, PA42-44, PA94-01, PV79-34, Pacovan Ken, Pacovan, Prata-Anã, Maravilha, Garantida, Princesa, Tropical, Maçã, Grande Naine, FHIA-02, Caipira, Bucaneiro e Thap Maeo. A severidade da Sigatoka amarela foi avaliada em 60, 270 e 420 dias após o plantio (DAP) (a partir de Julho/2009 até Julho/2010), utilizando uma escala descritiva de Stover. Em seguida, o índice de infecção foi calculado, aos 60, 270 e 420 DAP e comparados pelo teste de Scott-Knott a $5 \%$. Observou-se que os genótipos têm o mesmo comportamento a 270 DAP. Aos 60 DAP, genótipos com menor índice de infecção foram Bucaneiro, Enxerto-33, Japira-106, YB42-17, FHIA-02, FHIA-18, FHIA-23, PA42-44, PA94-01, Caipira, Maçã, PrataAnã e Thap Maeo. Aos 420 DAP, as taxas mais baixas foram obtidas para os genótipos YB42-17, FHIA-23, Princesa, YB42-47, Tropical, Grand Naine, Caipira, Macã, Garantida, Bucaneiro, Pacovan Ken e Thap Maeo.

Palavras-chave: Musa spp.. Banana-melhoramento genético. Plantas-resistência.

\footnotetext{
* Autor ppara correspondência

'Recebido para publicação em 19/02/2012; aprovado em 14/09/2013

Parte da Dissertação de Mestrado do autor principal apresentada no NEREN/UFS

${ }^{2}$ Programa de Pós-Graduação em Agroecossistemas, Departamento de Engenharia Agronômica, NEREN/UFS, São Cristovão-SE, Brasil, zilna_br@ hotmail.com; lucasfmo@bol.com.br

${ }^{3}$ Embrapa Tabuleiros Costeiros, Aracaju-SE, Brasil, ana.ledo@embrapa.br, viviane.talamini@embrapa.br

${ }^{4}$ Programa de Pós-Graduação da Rede Nordeste de Biotecnologia, Departamento de Química, RENORBIO/UFS, São Cristovão-SE, Brasil, kelly.cris.teixeira@gmail.com
} 


\section{INTRODUCTION}

Yellow Sigatoka (YS) stands out as a serious problem for banana culture in Brazil, being endemic in all states with severity peaks during the rainy season. It is responsible for reductions of green leaf area of the plant, resulting in smaller number of fruits per cluster, smaller number of bunches, smaller fruit size, early ripening of fruits in the field or after harvest. There are estimates that losses reached $50 \%$ of production, but depending on environmental conditions of each region, they can reach $100 \%$ (CORDEIRO; MATOS, 2005).

Mycosphaerella musicola Leach is the etiologic agent of YS. The genus Mycosphaerella has been studied in several crops such as wheat (M. graminicola), pea ( $M$. pinodes) and strawberry (M. fragariae), but the etiologic agents of black Sigatoka (M. fijiensis) and YS stand out in this context due to the economic impact caused by these diseases, by limiting the banana production in Brazil and worldwide (CHURCHILL, 2011; KABBAGE et al., 2008; MANZO-SÁNCHEZ et al., 2008; MAZARO et al., 2006; RIVAS et al., 2004; SETTI et al., 2011).

The damage caused by YS is solvable via genetic improvement. The final steps of a genetic improvement program, agronomic evaluation of cultivars in field and market evaluation are essential to the recommendation of new cultivars for use by farmers (AZEVEDO et al., 2010). Before replacing a cultivar, it is necessary to know the new genotype through characterization and evaluation studies in different ecosystems (LIMA et al., 2005).

To be used in the evaluation of cultivars resistant and/or tolerant to many diseases, diagrammatic scales reduce the subjectivity of estimates and provide more precise information about pathosystems, provide a standardized assessment of severity, thus allowing comparing results between different institutions and locations (LENZ et al., 2009). Studies have been conducted to determine the epidemiology and assess the severity of diseases in several economically important crops such as sunflower (LENZ et al., 2009), citrus (SILVA et al., 2009), apple (BOGO et al., 2010), tomato (FIORINI et al., 2010) and coffee (PAIVA et al., 2011).

Results on the behavior of banana cultivars in relation to $M$. musicola under natural infection conditions in different environments have been published by several authors (BORGES et al., 2011; CORDEIRO; MATOS, 2005; DONATO et al., 2009; LESSA et al., 2009; OLIVEIRA et al., 2008; PERUCH; SONEGO, 2007; ROCHA, 2008), who observed the formation of resistant, susceptible, moderately susceptible or highly susceptible groups, depending on the location of evaluation.
Studies on pathogenic variability and variety resistance have shown virulence variation in isolates, indicating the presence of vertical resistance, characterized by the presence of significant differential interaction between isolate and cultivate, shown in all studies conducted. Thus, obtaining a durable vertical resistance of selected genotypes and resistance tests with the greatest possible number of pathogenic variants that represent the predominant populations in different producing regions in the country becomes indispensable (CORDEIRO; MATOS, 2005).

Herefore, the objective of this study was to evaluate the behavior of banana genotypes regarding the YS severity under the environmental conditions of the Coastal Tablelands of Sergipe.

\section{MATERIAL AND METHODS}

The experiment was conducted in May 2009 at the Jorge do Prado Sobral Experimental Field of Embrapa Tabuleiros Costeiros in the municipality of Nossa Senhora das Dores, Sergipe, coastal tablelands area, whose coordinates are: $10^{\circ} 27^{\prime} 50.0^{\prime \prime} \mathrm{S}$ and $37^{\circ} 11^{\prime} 39.5^{\prime \prime} \mathrm{W}$ and altitude of $208 \mathrm{~m}$ above the sea level. The soil was classified as typical distrocohese Yellow Oxisol, A horizon moderate, clayey texture, flat terrain with intermediate fertility. The local climate is semi-humid, with winter and autumn rains, with annual average of $1.161 \mathrm{~mm}$, of which $74 \%$ are distributed from April to September. The average temperature is $25^{\circ} \mathrm{C}$ and relative humidity is $77 \%$.

The plantlets were initially acclimatized for two months in greenhouse and then planted in $3.00 \mathrm{~m} \mathrm{x} 2.00 \mathrm{~m}$ spacing, in rain system. Planting and cultural practices were carried out based on technical recommendations and fertilization was performed according to soil analysis and crop requirements.

The experimental design was randomized complete blocks, due to environmental variations (MURRAY, 2005), with 22 treatments (genotypes) and three replications, totaling 66 plots and 396 plants $\left(2.376 \mathrm{~m}^{2}\right)$. Each plot $\left(36 \mathrm{~m}^{2}\right)$ consisting of six plants arranged in row being considered four central plants useful (MATTOS et al., 2010). The outer boundary of the experimental area consisted of Prata-Anã cultivar. The treatments consisted of 22 genotypes: Prata (YB42-17, YB42-47, FHIA-18, PA42-44, PA94-01, PV79-34, Japira-106, Pacovan Ken, Pacovan, Prata-Anã, Maravilha, Garantida, Enxerto-33), Maçã (Princesa, Tropical, Maçã), Cavendish (Grande Naine, FHIA-02), Caipira (Caipira), Gros Michel (Bucaneiro, FHIA-23) and Mysore (Thap Maeo). Each plot consisting of six clumps arranged in row being considered four central 
clumps useful. The outer boundary of the experimental area consisted of Prata-Anã cultivar.

The yellow Sigatoka (YS) severity was assessed at 60, 270 and 420 days after planting (DAP), using a descriptive scale proposed by Stover (1971), according to the following grade scale: 0 : without symptoms; 1 : Less than $1 \%$ of the leaf blade with symptoms (presence of grooves and/or more than 10 spots), $2: 1-5 \%$ of the leaf blade with symptoms, 3: 6-15\% of the leaf blade with symptoms, 4: 16-33\% of the leaf blade with symptoms, 5: $34-50 \%$ of the leaf blade with symptoms, $6: 51-100 \%$ of the leaf blade with symptoms.

After collecting data on YS severity, the infection rate $(\%)$ of each genotype was determined using formula proposed by Stover (1971):

Infection rate-IR $(\%):\left[\sum_{\mathrm{n}} * \mathrm{~b} /(\mathrm{N}-1) * \mathrm{~T}\right] * 100$

where $\mathrm{n}=$ number of leaves in each level of the Stover's scale; $\mathrm{b}=$ scale degree; $\mathrm{N}=$ number of degrees used in the scale; $\mathrm{T}=$ total number of leaves evaluated.

Infection rates obtained at 60 (beginning of the vegetative phase), 270 (intermediate phase of vegetative development) and 420 (production phase) days after planting were submitted to analysis of variance by $\mathrm{F}$ test and grouped by Scott - Knott test (SCOTT; KNOTT, 1974) at 1 and 5\% probability using the Sisvar statistical software (FERREIRA, 2011).

\section{RESULTS AND DISCUSSION}

There were differences $(\mathrm{P} \leq 0.01)$ for the IR in the different genotypes at 60 and 420 DAP; however, at 270 DAP, no significant difference was observed (P>0.05). At 60 DAP (July/2009), genotypes that showed the highest infection rates were: PV79-34, Thap Maeo, Garantida, Maravilha, Tropical, Pacovan, Pacovan Ken and Prata-Anã. The other genotypes showed the lowest IR for this season (Table 1).

In study conducted by Peruch and Sonego (2007) evaluating the resistance of 21 banana genotypes to YS, cultivar Thap Maeo was ranked as highly resistant. However, cultivars Prata, Grand Naine, Pacovan and Enxerto were susceptible under organic farming conditions in the South Coast of Santa Catarina. In this study, at 60 DAP, cultivar Thap Maeo showed the highest infection rate compared to other genotypes, contrary to literature, while cultivar Caipira showed low infection rates.

In the Recôncavo Baiano region, state of Bahia, Lessa et al. (2009) evaluated hybrid diploids (AA) and found that the YS severity scores at the time of bunch emission ranged from 2.04 to 3.53 , and hybrids
8987-01, 1318-01 and 4223-06, even with intermediate susceptibility, showed the largest amounts of live leaves in the harvest.

At 420 DAP in July 2010, significant difference was observed between genotypes by the F test at $1 \%$ probability (Table 1). At 420 DAP, the IR assessed was higher in all genotypes. During this period, plants came into fructification process and this process may have contributed to increased susceptibility to YS. Genotypes with the highest IR were: Enxerto-33, PA42-44, FHIA-02, PV79-34, Maravilha, PA94-01, Pacovan and Prata-Anã. The other genotypes showed the lowest mean disease severity.

Assessing the resistance expression of banana varieties to YS with artificial inoculation of different M. musicola isolates, Cordeiro and Matos (2005) concluded that in all varieties, the post-inoculation reaction showed the formation of lesions in the form of dots or grooves barely perceptible.

In studies conducted by Donato et al. (2009) in the irrigated perimeter of Estreito, southwestern Bahia, cultivar Prata-Anã was more susceptible to YS and hybrid PA42-44 was the most resistant, but similar in productivity. In this study, in the Coastal Tablelands of Sergipe, cultivar Prata-Anã was used as susceptible control, and the IR values of this cultivar were significantly higher than the other cultivars.

Genotypes Bucaneiro and YB42-17 considered YS resistant (LIMA et al., 2005), showed the lowest IR values in the Coastal Tablelands region of Sergipe.

Genotype Enxerto-33 is susceptible to YS (PERUCH; SONEGO, 2007), which was observed in the results, but the severity observed in genotype PV79-34 is not in agreement with literature, since it is considered resistant to the disease and showed high IR in this study.

This differentiated response of genotypes with respect to the YS severity is probably due to the trial site, amount of inoculum, pathogen variability in sexual phase and environmental variables. According to Cordeiro and Matos (2005), although it is quite easy to select vertical resistance, it can be easily overcome by the pathogen, especially in the case of M. musicola, which has high pathogenic variability.

Several studies have been conducted in different periods of the banana cycle in order to monitor disease severity in different genotypes. In the Zona da Mata region, state of Minas Gerais, Oliveira et al. (2007) evaluated three banana cycles, incidence of YS in the flowering and harvest periods, and vegetative characteristics. Concerning the incidence of YS in the flowering period, a reduction from first to third cycle was observed in genotypes Pioneira, 
Table 1 - Area under the disease progress curve (AUDPC) and infection rate of yellow Sigatoka in 22 banana genotypes at 60; 270 and 420 days after planting (DAP), Nossa Senhora das Dores-SE

\begin{tabular}{|c|c|c|c|}
\hline \multirow{2}{*}{ Genotype } & \multicolumn{3}{|c|}{ Infection Rate $(\%)$} \\
\hline & 60 DAP & $270 \mathrm{DAP}$ & 420 DAP \\
\hline Enxerto-33 & $5.16 \mathrm{a}$ & $8.28 \mathrm{a}$ & $44.53 \mathrm{~b}$ \\
\hline Japira-106 & $4.90 \mathrm{a}$ & $11.42 \mathrm{a}$ & $33.17 \mathrm{~b}$ \\
\hline YB42-17 & $5.68 \mathrm{a}$ & $11.20 \mathrm{a}$ & $27.56 \mathrm{a}$ \\
\hline FHIA-18 & $3.69 \mathrm{a}$ & $5.77 \mathrm{a}$ & $33.65 \mathrm{~b}$ \\
\hline FHIA-23 & $6.03 \mathrm{a}$ & $11.93 \mathrm{a}$ & $30.44 \mathrm{a}$ \\
\hline PA42-44 & $5.94 \mathrm{a}$ & $11.26 \mathrm{a}$ & $36.62 \mathrm{~b}$ \\
\hline FHIA-02 & $2.48 \mathrm{a}$ & $8.60 \mathrm{a}$ & $38.00 \mathrm{~b}$ \\
\hline PV79-34 & $11.40 \mathrm{~b}$ & $14.31 \mathrm{a}$ & $40.56 \mathrm{~b}$ \\
\hline Maravilha & $14.75 \mathrm{~b}$ & $12.99 \mathrm{a}$ & $36.27 \mathrm{~b}$ \\
\hline Princesa & $8.77 \mathrm{~b}$ & $16.24 \mathrm{a}$ & $29.16 \mathrm{a}$ \\
\hline YB42-47 & $9.88 \mathrm{~b}$ & $11.64 \mathrm{a}$ & $29.47 \mathrm{a}$ \\
\hline Tropical & $14.26 \mathrm{~b}$ & $10.73 \mathrm{a}$ & $29.19 \mathrm{a}$ \\
\hline PA94-01 & $7.22 \mathrm{a}$ & $10.96 \mathrm{a}$ & $34.51 \mathrm{~b}$ \\
\hline Grande Naine & $9.01 \mathrm{~b}$ & $13.73 \mathrm{a}$ & 29.65 a \\
\hline Caipira & $7.03 \mathrm{a}$ & $15.67 \mathrm{a}$ & $30.21 \mathrm{a}$ \\
\hline Maçã & $5.90 \mathrm{a}$ & $14.85 \mathrm{a}$ & $26.47 \mathrm{a}$ \\
\hline Garantida & $15.86 \mathrm{~b}$ & $8.28 \mathrm{a}$ & $27.60 \mathrm{a}$ \\
\hline Bucaneiro & $1.85 \mathrm{a}$ & $9.60 \mathrm{a}$ & $29.36 \mathrm{a}$ \\
\hline Pacovan Ken & $9.78 \mathrm{~b}$ & $12.45 \mathrm{a}$ & $30.69 \mathrm{a}$ \\
\hline Pacovan & $12.13 \mathrm{~b}$ & $10.98 \mathrm{a}$ & $37.39 \mathrm{~b}$ \\
\hline Prata-Anã & $9.86 \mathrm{~b}$ & $10.66 \mathrm{a}$ & $40.84 \mathrm{~b}$ \\
\hline Thap Maeo & $21.70 \mathrm{a}$ & $15.39 \mathrm{a}$ & $24.95 \mathrm{a}$ \\
\hline F value & $69.26^{* *}$ & $21.34 \mathrm{~ns}$ & $81.82 * *$ \\
\hline $\mathrm{VC}(\%)$ & 23.12 & 21.76 & 7.59 \\
\hline
\end{tabular}

Means followed by same letter in column do not differ significantly by the Scott-Knott test at 5\% significance. *Significant at $1 \%$ probability

FHIA-18 and Prata-Anã. In the analysis of the average of all genotypes in each cycle, a gradual decrease of damages caused by YS was observed. According to the authors, this behavior stems from the fact that banana crops only establish after the second or third cycle, improving soil conditions and, consequently, the strength and ability to resist to diseases, which is a result dissimilar to that observed in the present study, where higher IRs were observed at the end of the first cycle.

Although YS is an important and widespread disease in Brazil and worldwide, further studies on the resistance and/or tolerance of banana genotypes to this disease and on its epidemiology in the different growing regions should be conducted.

\section{CONCLUSIONS}

1. The genotypes Enxerto-33, Japira-106, YB42-17, FHIA-02, FHIA-18, FHIA-23, PA42-44, PA94-01, Caipira, Maçã, Bucaneiro, Prata-Anã and Thap Maeo present the lowest lowest infection rates at $60 \mathrm{DAP}$;

2. The genotypes evaluated exhibit the same behavior with respect to the infection rate at $270 \mathrm{DAP}$;

3. The genotypes YB42-17, FHIA-23, Princesa, YB4247, Tropical, Grand Naine, Caipira, Maçã, Garantida, Bucaneiro, Pacovan Ken and Thap Maeo present the smallest infection rates at 420 DAP. 


\section{ACKNOWLEDGMENTS}

To the Brazilian Agricultural Research Corporation's (EMBRAPA), to the Foundation for Support to Innovation, Science and Technology of the State of Sergipe (FAPITEC-SE), to the Coordination for the Improvement of Higher Level -or EducationPersonnel (CAPES) and SERGIPETEC-SE for financial support and granting of research fellowships.

\section{REFERENCES}

AZEVEDO, V. F. de. et al. Avaliação de bananeiras tipo Prata, de porte alto, no Semiárido. Ciência e Agrotecnologia, v. 34, n. 6, p. 1372-1380, 2010.

BOGO, A. et al. Dinâmica temporal da mancha foliar da 'Gala' em macieiras conduzidas sob os sistemas de produção convencional e orgânico. Ciência Rural, v. 40, n. 2, p. 436-440, 2010.

BORGES, R. de S. et al. Avaliação de genótipos de bananeira no norte do Estado do Paraná. Revista Brasileira de Fruticultura, v. 33, n. 1, p. 291-296, 2011.

CHURCHILL, A. C. L. Mycosphaerellafijiensis, the black leaf streak pathogen of banana: progress towards understanding pathogen biology and detection, disease development, and the challenges of control. Molecular Plant Pathology, v. 12, n. 4, p. 307-328, 2011.

CORDEIRO, Z. J. M.; MATOS, A. P. Expressão da resistência de variedades de banana à Sigatoka-amarela. Fitopatologia Brasileira, v. 30, n. 5, p. 532-534. 2005.

DONATO, S. L. R. et al. Comportamento fitotécnico da bananeira 'Prata-Anã' e de seus híbridos. Pesquisa Agropecuária Brasileira, v. 44, n. 12, p. 1608-1615, 2009.

FERREIRA, D. F. SISVAR: a computer statistical analysis system. Ciência e Agrotecnologia, v. 35, n. 6, p. 1039-1042, 2011.

FIORINI, C. V. A. et al. Agrupamento de curvas de progresso de requeima, em tomateiro originado de cruzamento interespecífico. Pesquisa Agropecuária Brasileira, v. 45, n. 10, p. 1095-1101, 2010.

KABBAGE, M. et al. Genetic diversity of Mycosphaerella graminicola, the causal agent of Septoria tritici Blotch, in Kansas winter wheat. Journal of Agricultural, Food, and Environmental Sciences, v. 2, n. 1, 2008. Disponível em: <www.scientificjournals. org/journals2008/articles/1377.pdf >. Acesso em: 7 set 2012.

LENZ, G. et al. Escala diagramática para avaliação de severidade de mancha-de-septoria em girassol. Ciência Rural, v. 39, n. 8, p. 752-758, 2009.

MATTOS, L. A. et al. Agronomical and molecular characterization of banana germplasm. Pesquisa Agropecuária Brasileira, v. 45, n. 2, p. 146-154, 2010.
MAZARO, S. M. et al. Escala diagramática para avaliação da severidade da mancha-de-micosferela em morangueiro. Ciência Rural, v. 36, n. 2, p. 648-652, 2006.

LESSA, L. S. et al. Avaliação agronômica em híbridos diplóides (AA) de bananeira. Ciência e Agrotecnologia, v. 33, p. 17161721, 2009. Número Especial.

LIMA, M. B. et al. Avaliação de cultivares e híbridos de bananeira no Recôncavo Baiano. Ciência e Agrotecnologia, v. 29 , n. 3 , p. $515-520,2005$.

MANZO-SÁNCHEZ, G. et al. Construction of a genetic linkage map of the fungal pathogen of banana Mycosphaerella fijiensis, causal agent of black leaf streak disease. Current Genetics, v. 53, n. 5, p. 299-311, 2008.

MURRAY, L. Encyclopedia of biostatistics: randomized complete block designs. New York: John Wiley \& Sons Ltd., 2005. 143 p.

OLIVEIRA, C. A. P. de. et al. Genótipos de bananeira em três ciclos na zona da mata mineira. Pesquisa Agropecuária Brasileira, v. 42, n. 2, p. 173-181, 2007.

OLIVEIRA, T. K. de. et al. Características agronômicas de genótipos de bananeira em três ciclos de produção em Rio Branco, AC. Pesquisa Agropecuária Brasileira, v. 43, n. 8, p. 1003-1010, 2008.

PAIVA, B. R. T. L. et al. Progresso da ferrugem do cafeeiro irrigado em diferentes densidades de plantio pós-poda. Ciência e Agrotecnologia, v. 35, n. 1, p. 137-143, 2011.

PERUCH, L. A. M.; SONEGO, M. Resistência de genótipos de bananeiras à Sigatoka Amarela sob cultivo orgânico. Revista Brasileira de Agroecologia, v. 2, n. 3, p. 86-93, 2007.

RIVAS, G. G. et al. Founder effects and stochastic dispersal at the continental scale of the fungal pathogen of bananas Mycosphaerella fijiensis. Molecular Ecology, v. 13, n. 2, p. 471-482, 2004.

ROCHA, H. S. Epidemiologia da Sigatoka amarela, quantificação de fenóis em variedades de bananeiras e análise filogenética de isolados de Mycosphaerella musicola utilizando microssatélites. 2008, 141 p. Tese (Doutorado em Fitopatologia) - Universidade Federal de Lavras, Minas Gerais, 2008.

SCOTT, A. J.; KNOTT, M. A. A cluster analysis method for grouping means in the analysis of variance. Biometrics, v. 30 , n. 3, p.507-512, 1974

SETTI, B. et al. Morphological and virulence variation among isolates of Mycosphaerella pinodes the causal agent of pea leaf blight. African Journal of Agricultural Research, v. 6, n. 5, p. 1067-1075, 2011.

SILVA, S. X. de B. et al. Amostragem, caracterização de sintomas e escala diagramática da mancha graxa dos citros (Mycosphaerella citri) no Recôncavo Baiano. Ciência Rural, v. 39, n. 3, p. 896-899, 2009.

STOVER, R. H. A proposed internacional scale for estimating intensity of banana leaf spot (Mycosphaerella musicola). Tropical Agriculture, v. 48, n. 3, p. 85-196, 1971. 